\title{
The Mediating Effect of the Islamic Religious Personality on the Relationship between the Islamic Worldview and Intercultural Sensitivity among Students
}

\author{
Noorhannah Noorfuad \& Saodah Wok \\ Internation Islamic University Malaysia
}

\begin{abstract}
Muslims consider themselves to be a 'family of believers' (Samovar, 2009) as Islam emphasizes the importance of perceiving and treating other Muslims beyond the differences of appearance and culture. This study examines the relationships of the Islamic worldview and Islamic religious personality with intercultural sensitivity, as well as the mediating effect of the Islamic religious personality on the relationship between the Islamic worldview and intercultural sensitivity in an international learning institution. Religion has an essential role in culture and thus affects our beliefs and behavior. A survey method is used with questionnaire as the instrument for data collection. A sample of 221 undergraduate students of the International Islamic University of Malaysia (IIUM) participated in the study. The results show that the Islamic worldview and the Islamic religious personality positively influence intercultural sensitivity among Muslim students, and that the Islamic religious personality acts as a mediator in the relationship between the Islamic worldview and intercultural sensitivity.
\end{abstract}

Keywords: Intercultural communication; intercultural sensitivity; Islam; religiosity; worldview.

\section{Introduction}

The International Islamic University of Malaysia (IIUM) was founded in 1983, offering a comprehensive education that encompasses world knowledge with Islamic philosophy and values. Its main medium of instruction being English and/or Arabic, instead of the national Malay language, plays a part in strengthening its international positioning. Presently, the student population numbers about 30,000 with international students coming from 120 countries, such as Indonesia, Palestine, Germany, China and the United States of America. This mix of nationality and culture in an environment where religion, Islam, is a common factor brings forth exploratory possibilities in communication and cultural studies that can be carried out from an Islamic perspective.

The purpose of this study is to examine the relationship between the level of Islamic religiosity on the level of intercultural sensitivity among Muslim students in IIUM. Early research on intercultural sensitivity were conducted mostly in the West - discussing on findings that include individualism and collectivism as possible constructs to measure intercultural sensitivity (Bhawuk \& Brislin, 1992), intercultural sensitivity as an emotional aspect of intercultural communication competence and the basis for the development of the Intercultural Sensitivity Scale (Chen \& Starosta, 2000), the validation of various intercultural sensitivity scales on different Western cultural contexts (Fritz \& Chen, 2001; Lee Olson \& Kroeger, 2001; Banos, 2006) and more. Subsequently, more studies were carried out around the world that included exploring intercultural sensitivity in multicultural contexts and collectivistic communities such as those in the Asian region. Specifically in Malaysia, a country of diverse ethnicities and lifestyles, the concept of intercultural sensitivity has been examined for its effectiveness on cross-cultural adaptations (Awang-Rozaimie et al., 2013), with various scales tested in different contexts (Tamam, 2010; Yunus et al., 2017), its 
contributions to intercultural communication competence and relationship with religion (Nadeem, 2017; Nadeem 2017), and more. This study serves to look deeper into the Muslim community, by studying the extent to which religion affects how sensitive its members are to those of other cultures, especially in an increasingly diverse country like Malaysia.

\section{Background of study}

Due to the technological advancements that facilitate the movement of people and information across borders, the world becomes even more interconnected and interdependent (Chen, 2014). In travelling, people are now going to places for both business and leisure, representing their communities while exploring and experiencing cultures which are different from their own (Bremer 2006, Deardorff \& Hunter 2006, Matveev 2017). A university that prides in its holistic education and Islamic principles, IIUM welcomes Muslim students of various cultural backgrounds from all over the world to Malaysia, a country that is itself not a stranger to multicultural and ethnic diversity.

According to the World Factbook, Malaysia has a population of more than 31 million in the country, comprising the Malays as the majority race, followed by the Chinese, Indians, and other minority races ${ }^{1}$. More than half of the population claims Islam as their religion, with one-fifth claiming Buddhism and the remaining being Christian, Hindu, atheist or of other faiths ${ }^{2}$. These differences in culture and religion, however, do not pose a barrier against peace and harmony in the society. Mirroring this onto the environment of IIUM, although students hail from different backgrounds around the world, Islam connects everyone together. Since Islam propagates equality and empathy, putting faith and character first before nationality or culture, it should thus be expected that the students of IIUM have good intercultural communication skills and sensitivity.

According to Lee Olson and Kroeger (2001), intercultural communication takes place whenever individuals interact or communicate. However, it is not to an individual's instinct to respond with inherent sensitivity when faced with a situation of intercultural interaction. Here, religion plays a part in mediating an appropriate response in situations of intercultural interaction. Almost all aspects of a Muslim's life are guided by and immersed in Islam, which would then influence a Muslim to exercise tolerance and sensitivity when interacting with those of cultures or backgrounds different from theirs (Abu Raiya et al., 2008).

\section{Problem statement}

The increasing diversity of communities and institutions necessitates an individual to be highly involved in intercultural communication, especially significant for a multicultural and multi-religious country like Malaysia, so as to achieve national unity, peace, security, and economic growth (Tamam, 2010). In multi-religious Malaysia, Islam is the religion that is practised by the majority. As Islam emphasises on practising good intercultural relations, one can then expect that the stronger a Muslim is in his/her faith and practice his/her religion, the more sensitive and better understanding he/she should be to other cultures, as long as it does not threaten his/her faith (Ameli \& Molaei, 2012). There is, however, a seemingly lack of studies on the relationship between religiosity and intercultural sensitivity, which is what this research hopes to address.

\footnotetext{
${ }^{1}$ https://www.cia.gov/library/publications/the-world-factbook/geos/my.html

2 ibid
} 


\section{Objectives of study}

The objectives for this study are as follows:

i. To determine a relationship between the Islamic worldview, the Islamic religious personality and intercultural sensitivity among students; and

ii. To determine the mediating effect of the Islamic religious personality in the relationship between the Islamic worldview and intercultural sensitivity of students in IIUM.

\section{Significance of the study}

This study is significant in its potential contribution to literature on religious identity and intercultural sensitivity. It is also hoped that the findings and implications could be used as a basis in the development of university policies, curriculum and activities to bring awareness to and promote intercultural sensitivity amongst staff and students for respectful understanding, harmony and goodwill on campus.

\section{Literature review}

According to Anderson (2015) and Mahudin et al. (2016), religion continues to play a main role in the lives of individuals and the larger community even though it has been seemingly subdued by secularization and contemporary times. This is especially demonstrated in Malaysia - a collectivistic country in which culture and religion are strongly held by in daily life alongside the achievement of impressive levels of progress and development (Noon 2003; Mun et al., 2017). In addition to the multi-ethnic local community, international travel and migration has also contributed to the variety of cultures and backgrounds in the country.

Practised by the majority in Malaysia, the religion of Islam encompasses physical action (Islam), faith and understanding of God (Iman), as well as the expression of good character (Ihsan). It is ihsan, righteousness in character and sincerity in actions, that is the highest level of submission to God that a Muslim can attain (Mahudin et al., 2016). It is described in the hadith that the Prophet (SAW) described ihsan as: "To worship Allah as if you see Him, and if you cannot achieve this state of devotion then you must consider that $\mathrm{He}$ is looking at you" (Sahih al-Bukhari 50). This encompasses all our daily actions - our work and tasks, as well as in our social interaction - which we should strive to perform in excellence (Shuriye, 2014). Having ihsan in our social interactions would also mean being sensitive in our interactions with others, especially those of other cultures and backgrounds which is a largely inevitable occurrence today. Therefore, in this study, where the concept of Iman or faith will be examined by the construct of the Islamic Worldview and the concept of Islam or physical worship by the construct of Religious Personality, the construct of intercultural sensitivity will then be used to examine the concept of Ihsan or good character.

\section{Islamic Worldview}

The Islamic Worldview comprises the doctrine of the religion, which is measured by examining the understanding and agreement of a Muslim towards central Islamic beliefs and teachings. The rich history of Islam has shown how Muslim communities had transcended cultural barriers to maintain peace, harmony and unity with faith as the central factor. According to Abd-Allah (2009), Ibn Battuta had narrated of his travels that regardless of the many cultures he encountered, the familiar culture of Islam even while intertwined with local customs made him feel 'at home'. The advent of Islam into these communities only affected what was inherently harmful to Man and did not bring drastic changes to or eliminate the deep-seated customs of an entire society, as long as they are not in conflict with Islamic ethics. 
Islam recognizes that culture makes up a solid part of identity, ensuring well-being and protecting from harm in ways that differ with each community (Abd-Allah 2009).

Islam encourages intercultural interaction and emphasizes its importance in the Holy Qur'an through verses that address differences in humanity as well as righteousness in cultural acceptance: "O mankind, indeed We have created you from male and female and made you peoples and tribes that you may know one another," (Al-Hujurat: 13). The Prophet (SAW), whose character is described as the embodiment of the Qur'an, also advocates equality and non-discrimination among people, as he reminded in his final sermon and also in his sayings (Ibrahim, 2014) as narrated by his wife, 'Aisha, as follows:

All mankind is from Adam and Eve; an Arab has no superiority over a nonArab nor a non-Arab has any superiority over an Arab; also a White has no superiority over a Black nor a Black has any superiority over a White except by piety and good action. Learn that every Muslim is a brother to every Muslim and that the Muslims constitute one brotherhood.

\section{Religious Personality}

Religious personality delineates the personal behaviours and practices of a Muslim that are based on or are relevant to Islam. These include personal acts of worship and behaviour as well as interactions with other people. Where a number of studies on religiosity are carried out based from a Christian context (Allport \& Ross, 1967; Glock \& Stark, 1965), there have been studies on religiosity from the Islamic context that are well founded (Albehairi \& Demerdash, 1988; Ilyas, 1992; Wilde \& Joseph, 1997; Sahin \& Francis, 2002; Noon et al., 2003; Conroy \& Emerson, 2004; Krauss et al., 2006; Alghorani, 2008; Abu Raiya, 2008).

These studies examine religiosity in Islam from the perspective of single or multiple dimensions (Noon et al., 2003) through the understanding of foundational Islamic principles such as tawheed and taqwa (Ilyas, 1992), Islamic knowledge and practices (Alghorani, 2008; Conroy \& Emerson, 2004), and more. Approaches to measuring religiosity stem from different aspects such as attitudes (Wilde \& Joseph, 1997; Sahin \& Francis, 2002), psychological well-being (Abu Raiya, 2008), personality (Krauss et al., 2006), and intrinsic and extrinsic religious orientation (Albehairi \& Demerdash, 1988), amongst many different measures.

To comprehensively investigate the levels of religiosity of a Muslim community, this study chooses to consider the Muslim Religiosity-Personality Inventory (MRPI) (Krauss, et al., 2006). The MRPI is a self-reporting instrument for Muslims on their levels of religious perspective and personality, which was developed directly from a Muslim context by accounting for religious views and habits. Research has also shown influences of personality and religion on social interaction and harmony (Saroglou, 2015), which matches our selection of the MRPI in this study on intercultural sensitivity.

\section{Intercultural Sensitivity}

The notion of intercultural sensitivity was studied as early as 1958 and its concept much disputed among scholars. It first began with Bronfenbrenner, Harding and Gallwey (1958) who define it as the ability to be aware of differences in the thoughts, actions or feelings of people from various backgrounds. Hart and Burks (1972) and Hart, Carlson and Eadie (1980) consider intercultural sensitivity as a mindset or way of thinking. Bennett (1993), however, 
came up with a developmental process of transformation in which a person can gradually shift from a stage of judging other cultures from the limited perspective of one's own (ethnocentrism) to that of perceiving all cultures as equal and valid with differences of their own rights (ethno-relativism), according to changes in their opinions brought about by personal experiences. Nevertheless, these notions of intercultural sensitivity are still commonly based upon the three domains of affect, cognition and behaviour.

Bhawuk and Brislin (1992) digresses from this basis to explain and measure intercultural sensitivity in terms of Hofstede's cultural dimensions (2011), specifically in the dimension of individualism and collectivism in intercultural interaction. To date, there are studies which utilize the individualist-collectivist dimension of Hofstede across different religions as well as within religions (Tarakeshwar, Stanton \& Pargament, 2003; Cohen, Wu \& Miller, 2016). However, there have been challenges in measuring sensitivity and competency in interaction across culture and religion simultaneously due to overlaps in the two variables.

Chen (1997, p. 5) describes intercultural sensitivity as follows: "an individual's ability to develop positive emotion towards understanding and appreciating cultural differences that promotes appropriate and effective behaviour in intercultural communication", developing the Intercultural Sensitivity Scale (ISS) in the process. Tamam (2010) carried out the ISS on 447 university students of Malaysia to determine whether Chen's model (1997) could be similarly upheld in a non-Western context that is multicultural and collectivistic - one in which intercultural sensitivity is largely emphasized upon. It was found that the multicultural Malaysian setting was slightly more homogenous, deriving three factors from the Factor Analysis than Chen's original five-factor model carried out in the West (1997).

\section{Conceptual framework of study}

According to Krauss et al. (2006), religiosity is explained through two constructs - Islamic Worldview and Religious Personality. The framework highlights the significance of knowledge and action in Islam which are key areas of focus in this study.

\section{Islamic Worldview \& Religious Personality}

Krauss et al. (2006) study religiosity in Islam based on the principle of divine unity (Tawhidic principle) and developed the Muslim Religiosity-Personality Inventory (MRPI). This instrument is based on the concept that Islamic religiosity can be expressed through two constructs - Islamic Worldview and Religious Personality - putting emphasis on knowledge essential to the religion as well as actions and practices pertaining to it.

It was narrated by Abu 'Abdullah that the Prophet considered these principles - the tenets of acts of worship (Islam), principles of faith (Iman) and good moral character (Ihsan) - to be a part of faith (Sahih al-Bukhari 50). Therefore, it can be conjectured that a strong foundation in the Islamic worldview (Islam) and high levels of religious personality (Iman and Ihsan) would be positively related.

H1: There is a positive significant relationship between the Islamic worldview and religious personality. 


\section{Islamic Worldview \& Intercultural Sensitivity}

In a collectivistic society in which people are interdependent on the impressions and acceptance of others, maintaining good rapport, harmony and mutual cooperation is important. Even with Islam established as the official religion of the country, tolerance and intercultural sensitivity is very much emphasized upon. These values are deemed humanistic and is part of being moral and ethical in a society. In Islam particularly, the principles underlying intercultural communication as presented in the Qur'an is based on the values of shared humanity (Ibrahim, 2014). The Qur'an recognizes 'human difference' as an inherent feature that is essential to humankind and endorses plurality and interaction across differences without disparaging cultural specificities (Ibrahim, 2014; Wani et al., 2015; Izelmaden, 2016).

Where major monotheistic religions, including Islam, advocate universal moral principles, it is found that followers of such religions are less willing to act unethically and are more likely to demonstrate moral sentiments (Conroy \& Emerson, 2004; Idris et al., 2016) such as being sensitive and understanding to others. It can then be supposed that having a firm Islamic worldview would reinforce an individual's levels of intercultural sensitivity.

$\mathrm{H} 2$ : There is a positive significant relationship between the Islamic worldview and intercultural sensitivity.

\section{Religious Personality \& Intercultural Sensitivity}

In an environment where Muslims are a majority and yet where there is also a high exposure to cultural diversity like Malaysia, the devout practice of one's faith is emblematic of the extent of how tolerant and understanding one should be (Idris et al., 2016). As the faith of Muslims in Malaysia is comfortably manifested in their obligatory and personal religious practices, it is natural for them to incline towards moral competence, which would include intercultural sensitivity, as a form of adhering to their faith. This study thus hypothesizes that a strong practice of Islam will positively affect the levels of intercultural sensitivity.

H3: There is a positive significant relationship between religious personality and intercultural sensitivity.

\section{Islamic Worldview \& Intercultural Sensitivity, with mediator Religious Personality}

As an important part of culture, religion has a significant role in shaping a person's character and understanding of the world (Holcomb 1957; Muhamad 2009). This is because the rules and teachings of a religion can directly influence how a person makes sense of a situation as well as their actions towards others. The religious practices in Islam, for example, train one to be humble and to always think good of others. Therefore, where religious practice and principle encourage having good character and respectful relations with others, it can be said that religion is likely to positively affect one's level of intercultural sensitivity when interacting with those of different cultures (Ameli \& Molaei, 2012). It can then be hypothesized that religious personality would reinforce the Islamic worldview and thus have a positive mediating effect on intercultural sensitivity.

H4: Religious personality has a positive mediating effect on the relationship between Islamic worldview and intercultural sensitivity. 


\section{Methodology}

\section{Research Design}

This study utilizes a quantitative research design, with a questionnaire as the research instrument for data collection.

\section{Population and Sampling Procedure}

The population of the study consists of the youth in Malaysia who are both local as well as international tertiary students. Generally, between the ages of 20-30 years old, they are selected randomly from a stratified sample of students from the Department of Communication in IIUM. The total number of students in the department is 500, and 221 of them are selected to be respondents for this study.

\section{Research Instrument}

The questionnaire comprises-three sections; Section A on demographic information, Section B consists of items on religiosity (Islamic Worldview and Religious Personality), and Section C consists of items on intercultural sensitivity.

The Islamic Worldview component consists of 10 statements on a five-point Likert scale measuring respondents' understanding of the religious principles, ranging from (1) "Strongly disagree" to (5) "Strongly agree" for statements such as "All deeds performed by Rasulullah (SAW) were guided by revelation". The Religious Personality component consists of 22 statements on a five-point Likert-like scale measuring respondents' behaviour and practices that are representative of their Islamic understanding, ranging from (1) "Never" to (5) "Always" with statements such as "I find time to recite the Qur'an even if I am busy".

Scores are then summated and the mean calculated to generate an overall score. The higher the score for the Islamic worldview, the stronger the inclination towards a firm belief in the foundational principles of Islam. The higher the score for the Religious Personality, the higher the frequency that an individual performs the acts as stated.

For the section on intercultural sensitivity, respondents are to rate 15 statements adapted from the ISS (Chen \& Starosta, 2000) on a five-point Likert scale based on personal relevance, from (1) "Strongly disagree" to (5) "Strongly agree". An overall score is then computed and the higher score on the scale indicates a higher sensitivity to others in intercultural interaction.

\section{Validity and Reliability}

Table 1: Reliability of items for the selected variables

\begin{tabular}{lll}
\hline & \multicolumn{2}{c}{ Actual Study } \\
\hline Variables & No. of items & Cronbach alpha \\
\hline Islamic Worldview & 10 & .810 \\
Religious Personality & 22 & .908 \\
Intercultural Sensitivity & 15 & .924 \\
\hline
\end{tabular}


Both scales from which the statements are derived are reliable, with the MRPI having a 0.91 reliability coefficient and the Intercultural Sensitivity Scale having a 0.88 reliability coefficient. Nevertheless, a test of reliability has also been carried out on the adapted scales. The eventual results show a high reliability for all three variables as in Table 1: Islamic Worldview (.810), Religious Personality (.908), and Intercultural Sensitivity (.924). The statements are also cross-referred to ensure truth in content and writing form. The instrument was also shown to experts of the field who endorsed it.

\section{Data Collection}

The data was collected for two months between February 2018 and March 2018. It was conducted at the Gombak campus of IIUM. The questionnaires are in English and each takes about 15 minutes to complete.

\section{Data Analysis}

The data analyses of results are carried out in the Statistical Package for Social Sciences (SPSS) software. A partial correlations analysis is employed to determine the relationships among the three variables, as well as to find out the mediating effect of religious personality on the relationship between the Islamic worldview and intercultural sensitivity.

\section{Findings}

\section{Religious Personality as Mediator}

With reference to Table 2, there is a significant positive relationship between the Islamic worldview and religious personality $(\mathrm{r}=0.279, \mathrm{p}=0.000)$, although it can be considered weak. Likewise, the Islamic worldview also significantly correlates to levels of intercultural sensitivity to a positive extent $(\mathrm{r}=0.138, \mathrm{p}=0.041)$, although weak. This implies that a person's Islamic worldview could influence his actions, in terms of religious practices as well as interaction with others. However, the weak influence could perhaps be attributed to a perceived distinction in worldview between what is considered Islamic and what is considered secular, or even a disconnect between faith and action where what is believed might not necessarily reflect what is being done. Nevertheless, this shows that $\mathrm{H} 1$ and $\mathrm{H} 2$ are accepted.

Table 2: Partial correlations for religious personality

\begin{tabular}{llcc}
\hline Control Variables & $\begin{array}{c}\text { Intercultural Sensitivity } \\
\text { Mean }\end{array}$ & $\begin{array}{c}\text { Religious Personality } \\
\text { Mean }\end{array}$ \\
\hline & Islamic Worldview & $\mathrm{r}=.138$ & $\mathrm{r}=.279$ \\
& Mean & $\mathrm{p}=.041$ & $\mathrm{p}=.000$ \\
& Religious & $\mathrm{r}=.515$ & \\
& Personality Mean & $\mathrm{p}=.000$ & \\
\hline $\begin{array}{l}\text { Religious } \\
\text { Personality } \\
\text { Mean }\end{array}$ & Islamic Worldview & $\mathrm{r}=-.008$ & \\
& Mean & $\mathrm{p}=.912$ & \\
\hline
\end{tabular}

There is a stronger significant positive relationship between the religious personality and the levels of intercultural sensitivity $(\mathrm{r}=0.515, \mathrm{p}=0.000)$. This is a likely indication that the more frequent an individual practises his/her religious obligations, the more sensitive and understanding he/she is towards the differences of other cultures. H3 is therefore accepted as well. 
When controlling for the religious personality to identify mediating effect, there is a reduction in the relationship between the Islamic worldview and intercultural sensitivity by $2 \%$, where the correlation coefficient $(\mathrm{r})$ is decreased from $\mathrm{r}=.138$ to $\mathrm{r}=-.008$. The relationship is also found to be insignificant as $p=.000$ becomes- $p=.912$. This shows a full mediating effect. It can therefore be conjectured that the religious personality fully mediates the relationship between the Islamic worldview and intercultural sensitivity.

In this case, there is the possibility that an individual can become less sensitive towards those of different cultures from him/her when his/her religious personality is increasingly manifested, regardless of his/her Islamic beliefs and worldview. H4 is thus rejected. This result may perhaps suggest a perceived distinction by the students between religious behaviours and practices as enjoined by Islam and personal character in the form of intercultural sensitivity.

\section{Conclusion}

In conclusion, this study hopes to show how much Islam can positively influence our sensitivity towards others who are from different backgrounds. As Muslims, we should strive to develop and improve on our human conditions by seeking knowledge and constantly working towards harmony in our diversity (Izelmaden, 2016). Ideally, the more steadfast our religious personality, the more sensitive and understanding we should be towards those of different backgrounds. However, it has been found that although we may hold strongly to Islamic beliefs and rituals, the quintessential Islamic faith may not be manifest in our character and daily interaction. It is thus hoped that this study may contribute to an awareness of this rift and an initiative towards good character and intercultural interaction. Where research in the field of intercultural competency and sensitivity mostly study either diversity in culture or religion, this study addresses cultural diversity within a religion. Suggestions for further research would include qualitative studies that could delve deeper into the motivations and hindrances in intercultural interaction and sensitivity in diverse Muslim communities, and expanding the scope to study the working population in diverse and globalized Islamic institutions.

\section{References}

Abd-Allah, U. F. (2009). Islam and the cultural imperative. Islam and Civilisational Renewal, 1(1), 10.

Abu-Raiya, H. (2008). A psychological measure of Islamic religiousness: Evidence for relevance, reliability and validity. The International Journal for the Psychology of Religion. 18(4), 291-315. doi: 10.1080/10508610802229270

Albehairi, A., \& Demerdash, A. (1988). Religious orientation scale.

Alghorani, M. A. (2008). Knowledge-Practice Measure of Islamic Religiosity (KPMIR): A case of high school Muslim students in the United States. Journal of Muslim Mental Health, 3(1), 25-36.

Allport, G. W., \& Ross, J. M. (1967). Personal religious orientation and prejudice. Journal of personality and social psychology, 5(4), 432.

Ameli, S. R., \& Molaei, H. (2012). Religious affiliation and intercultural sensitivity: Interculturality between Shia \& Sunni Muslims in Iran. International Journal of Intercultural Relations, 36(1), 31-40.

Anderson, J. R. (2015). The social psychology of religion: The importance of studying religion using scientific methodologies. In B. Mohan (Ed.), Constructions of social psychology. Lisbon, Portugal: in Science Press 
Awang-Rozaimie, A. S., Amelia, A. T., Aiza, J., Siti-Huzaimah, S., \& Adib, S. (2013). Intercultural sensitivity and cross-cultural adjustment among Malaysian students abroad. Journal of Educational and Social Research, 3(7).

Banos, R. V. (2006). Intercultural sensitivity of teenagers: a study of educational necessities in Catalonia. Intercultural communication studies, 15(2), 16.

Bennett, M.J. (1993). Towards ethnorelativism: A developmental model of intercultural sensitivity. In R.M. Paige (Ed.), Education for the intercultural experience (2nd ed., pp. 21-71). Yarmouth, ME: Intercultural Press.

Bhawuk, D. P., \& Brislin, R. (1992). The measurement of intercultural sensitivity using the concepts of individualism and collectivism. International Journal of Intercultural Relations, 16(4), 413-436.

Bremer, D. (2006). Wanted: Global workers. International Educator, 15(3).

Bronfenbrenner, U., Harding, J., \& Gallwey, M. (1958). The measurement of skill in social perception. In D. McClelland (Ed.), Talent and society: New perspectives in the identification of talent. New York: Van Nostrand

Chen, G. M. (1997). A review of the concept of intercultural sensitivity. Human Communication, 1, 1-16.

Chen, G. M., \& Starosta, W. J. (2000). The development and validation of the intercultural sensitivity scale. Human Communication, 3, 1-15.

Chen, G. M. (2014). Intercultural communication competence: Summary of 30-year research and directions for future study. Intercultural communication competence: Conceptualization and its development in cultural contexts and interactions, 14-40.

Cohen, A. B., Wu, M. S., \& Miller, J. (2016). Religion and culture: Individualism and collectivism in the East and West. Journal of Cross-Cultural Psychology, 47(9), 1236-1249.

Conroy, S. J., \& Emerson, T. L. (2004). Business ethics and religion: Religiosity as a predictor of ethical awareness among students. Journal of Business Ethics, 50(4), 383-396.

Dalib, S., Harun, M., \& Yusof, N. (2017). Student intercultural competence in a Malaysian campus: A phenomenological approach. Journal of Multicultural Discourses, 12(1), 42-62.

Deardorff, D. K., \& Hunter, W. (2006). Educating global-ready graduates. International Educator, 15(3), $72-83$

Fritz, W., Mollenberg, A., \& Chen, G. M. (2001). Measuring intercultural sensitivity in different cultural context.

Glock, C. Y., \& Stark, R. (1965). Religion and society in tension. Chicago: Rand McNally.

Hart, R. P., \& Burks, D. M. (1972). Rhetorical sensitivity and social interaction. Communications Monographs, 39(2), 75-91.

Hart, R. P., Carlson, R. E., \& Eadie, W. F. (1980). Attitudes toward communication and the assessment of rhetorical sensitivity. Communication Monograph, 47(1), 1-22.

Hofstede, G. (2011). Dimensionalizing cultures: The Hofstede model in context. Online readings in psychology and culture, $2(1), 8$.

Holcomb, E. (1957). Religion as an agent in the development of character and personality. Religious Education, 52(3), 212-217.

Ibrahim, H. (2014). Approaches to reading intercultural communication in the Qur'an and the politics of interpretation. Critical Research on Religion, 2(2), 99-115.

Idris, F., Abdullah, M. R. N., Ahmad, A. R., \& Mansor, A. Z. (2016). The Effect of Religion on Ethnic Tolerance in Malaysia: The Application of Rational Choice Theory (RCT) 
and the Theory of Planned Behaviour (TPB). International Education Studies, 9(11), $13-24$.

IIUM site on The Last Sermon. Retrieved from http://www.iium.edu.my/deed/articles/thelastsermon.html 14 December 2017

Ilyas, S. (1992). Dimensions of Muslim religiosity: Measurement considerations. Islamabad, Pakistan: International Institute of Islamic Thought. Google Scholar.

Izelmaden, M. (2016). Diversity Management from an Islamic Perspective. In Cultural Roots of Sustainable Management(pp. 119-131). Springer, Cham.

Kapoor, S., \& Comadena, M. (1996). Intercultural sensitivity in individualist-collectivist setting. Paper presented at Intercultural Communication Convention, Albuquerque, New Mexico.

Krauss, S. E., Hamzah, A. H., Suandi, T., Noah, S. M., Juhari, R., Manap, J. H., ... \& Mahmood, A. (2006). Exploring regional differences in religiosity among Muslim youth in Malaysia. Review of Religious Research, 238-252.

Lee Olson, C., \& Kroeger, K. R. (2001). Global competency and intercultural sensitivity. Journal of Studies in International Education, 5(2), 116-137.

Mahudin, N., Noor, N., Dzulkifli, M., \& Janon, N. (2016). Religiosity among muslims: A scale development and validation study. Makara Hubs-Asia, 20(2), 109-121.

Matveev A. (2017) Describing intercultural competence. In: Intercultural competence in organizations. Management for professionals. Springer, Cham

Muhamad, R. (2009). Religiosity, ethical judgments and Malaysian Muslim students. Journal of Business Systems, Governance and Ethics, 4(1), 53.

Mun, A. S., Fern, C. P., \& Chin, L. C. (2017). Between ethnicization and globalisation: Mediating contesting cultural identities of Malaysian youths. Geografia-Malaysian Journal of Society and Space, 11(3).

Nadeem, M. U., Mohammed, R., \& Dalib, S. (2017). A Proposed Model of Intercultural Communication Competence (ICC) in Malaysian Context. International Journal of Educational Research Review, 2(2), 11-20.

Nadeem, M. U., Mohammed, R., \& Dalib, S. (2017). Religion and Intercultural Communication Competence. Religion, 28.

Noon, H. M., Haneef, M. A. M., Yusof, S. A., \& Amin, R. M. (2003). Religiosity and social problems in Malaysia. Intellectual Discourse, 11(1).

Sahih al-Bukhari 50. In-book reference: Book 2 Hadith 43. Retrieved from https://sunnah.com/bukhari/2

Sahin, A., \& Francis, L. J. (2002). Assessing attitude toward Islam among Muslim adolescents: The psychometric properties of the Sahin-Francis scale. Muslim Education Quarterly, 19(4), 35-47.

Samovar, L. A., Porter, R. E., \& McDaniel, E. R. (2009). Communication between cultures: Wadsworth Pub Co.

Sarglou, V. (2015). Personality and Religion. International Encyclopedia of the Social \& Behavioral Sciences, , 17, 801-808.

Shuriye, A. O. (2014). The Role of Tawheedic Stimulus in the Conscience of Muslim Individuals. Mediterranean Journal of Social Sciences, 5(23), 1940.

Tamam, E. (2010). Examining Chen and Starosta's model of intercultural sensitivity in a multiracial collectivistic country. Journal of Intercultural Communication Research, 39(3), 173-183. 
Tarakeshwar, N., Stanton, J., \& Pargament, K. I. (2003). Religion: An overlooked dimension in crosscultural psychology. Journal of Cross-Cultural Psychology, 34, 377-394.

The Noble Qur'an, Sahih International. Verses retrieved from https://quran.com/49 (AlHujurat) and https://quran.com/7 (Al-A'raf)

Wani, H., Abdullah, R., \& Chang, L. W. (2015). An Islamic perspective in managing religious diversity. Religions, 6(2), 642-656.

Wilde, A., \& Joseph, S. (1997). Religiosity and personality in a Moslem context. Personality and Individual differences, 23(5), 899-900.

Yunus, N., Tamam, E., Bolong, J., Adzharuddin, N. A., \& Ibrahim, F. (2017). Validation of intercultural sensitivity three-factor model in Malaysian context. In SHS Web of Conferences (Vol. 33). EDP Sciences. 